\title{
Construction of Feminine Ideology in Gusii Oral Poetry
}

\author{
Nyambane Fredrick Monanti Prof. Kitche Magak Dr. Jane Bwonya \\ Box 592-50200, Bungoma - Kenya
}

\begin{abstract}
Abagusii females of the Kisii community of Western Kenya are largely socialized through the community's oral poetry to operate within the limits of a feminine ideology. The choice of Gusii oral poetry as a vehicle for studying feminine ideology of Abagusii is informed by the fact that this genre of Gusii verbal arts is the oldest and most versatile genres of Gusii orature. Equally, it has had a long and intimate relationship with human communities globally. This paper thus examines the Gusii oral poems as a semiotic system with encoded signs which embody the Gusii feminine ideology. The objective of the paper is to establish the construction and nature of the Gusii feminine ideology and its efficacy in shaping social relationships within Abagusii as a social entity. In the analysis of the purposively sampled oral poems, this paper uses a conceptual framework developed from the Chandler (1995) strands of semiotics in which he argues that a culture produces signs and attributes meanings to them. The tenets of semiosis are then linked to the sociological literary theory strands of Rosenblatt (1978) in which he argues that literature mirrors protocols of the society which produces it and serves given social purposes. Finally, strands from the two literary theories of semiotics and sociological are further interlinked with the Althusserian (1989) and Eagleton (1976)'s tenets of Marxism in which they argue that art is a product of a specific historical epoch and its purpose is to be an Ideological State Apparatuses which interpellates people into becoming subjects of specific ideologies. This paper has adopted the analytical study design. Secondary data was obtained from a review of published works and primary data was the textual analysis of Gusii oral poems collected from the Abagusii resource persons, copyrighted music stores and libraries. The sampling of data and resource persons was both purposive and through snowballing. The study is significant in the sense that it contributes towards celebrating the role of oral poetry as a vehicle for enabling humans to perceive themselves, their environment and their world in ways unique to them and enhancing of intercultural relations as well as forms a basis for related studies.
\end{abstract}

Keywords: Construction, Feminine, Ideology, Oral poetry, Perceptions, Interpellation

DOI: $10.7176 / \mathrm{ADS} / 74-02$

Publication date:June $30^{\text {th }} 2019$

\section{Introduction}

From a historical perspective, Ochieng's (1974), has postulated that Abagusii also known as the Kisii are a Bantu speaking community currently occupying the South West portions of the Kenyan highlands; in the administrative twin counties of Nyamira and Kisii. Abagusii speak Ekegusii language. They recognize a common ancestor named Mogusii, hence a common ancestry and a common ideological heritage. The community is divided into seven clans and are neighbours to communities of unrelated language families except the Abakuria. These communities are the Nilotic-speaking Luo to the North, West, and to the South West; the Nilo-Hamitic Kipsigis to the East, and the Nilo-Hamitic Maasai to the South East. Finally, to the South, are the Kuria (Abatende), whose language is mutually intelligible with Ekegusii.

Abagusii, just like any human community world over, operate within the confines of specified ideologies. These ideologies are inculcated into their mindsets through various avenues and more often than not, through their oral poetry, the oldest of the genres studied in literature (Habib 2005) and one which has had an intimate relationship with the human societies for eternities. Abagusii as a distinct community perform and listen to their verbal arts and in the process, they engage in the process of perceiving themselves and their cosmos in a way that is unique to them. In the process of performing and consuming their oral poetry, they construct an ideological cosmos which defines their socio - cultural identities and limits. Equally, as they perform, they get "interpellated" into aligning their thinking and mannerisms according to the dictates of their own society, hence, the intention of this study to investigate the Gusii Feminine Ideology as constructed by the community's oral poetry.

\section{Reviewed Works}

The grounding of this study has starts with the reviewing of classical theoreticians such as Plato and Aristotle before engaging more recent critical works. The classical thinkers have averred that the relationship between oral poetry and ideology has provided ground for intellectually protracted discourses and has remained at the heart of many societies. In this regard, oral poetry was and still is at the centre of people's lives and through it, communities have continued to construct and review their worlds in regard to changing times. For this reason, this analysis anchors itself on the premise that the Gusii feminine ideology is a conscious social construct of their 
conscious actions and it is a reflection of their wishes as is artistically embodied in their oral poetry.

Plato (in Habib 2005), postulated that literary works expose images and that through those images, man is cast as chained deep within the recess of a cave. According to him, humans are bound, so their vision is restricted. This study intimates that what binds people and restricts their vision are the various ideologies which are constructed and inculcated into their mindsets through literary works. Ultimately, people's perceptions of their world are conditioned (bound) to subscribe to the specific ideologies as they are constructed through their various forms of art - oral poetry being one of them. One of the ideologies that can bind people is the feminine ideology, the one which this paper examines in relation to Abagusii. Plato (in Habib 2005) further avers that education through oral poetry is most sovereign. This is because more than anything else, rhythm and harmony when combined as it is the case with oral poetry, they find their way to the innermost soul of an individual and take strongest hold upon it. He further says that ideology operates and continues to operate by its formal expression rather than by its explicit content; thus, making oral poetry a powerful force in moulding public opinion. This is because oral poetry has got inbuilt ability to present arguments coherently and persuasively. These are profound insights to the study of poetry, hence, this study's analysis of Gusii oral poetry and documentation of the community's feminine ideology.

The Pan-Hellenist movement (Habib 2005) suggested that truths such as myths are social constructs enacted through oral poetry. Soyinka (1976) posits that a myth is a primal phenomenon which is an embodiment of nature and cosmic principles. In the Gusii orature context, this study points out that Gusii oral poetry embodies mythical standpoints which are instituted to explain the relevance of Abagusii's customs, to control and regulate their moral and social behaviour as well as protect and enhance their traditions and beliefs and in particular to the Gusii feminine ideology.

In Poetics, Aristotle (in Habib 2005) has stated that from childhood, men have an "instinct" for imitation. He affirms that human beings rely on imitation to learn and that through this process they infer the nature of each object. Therefore, for Aristotle, imitation is both a mode of learning which is associated with pleasure. He further postulates that philosophical mindsets and universal truths (ideologies) are espoused by poetry. These views by Aristotle are echoed by Ngugi (1978) who correctly states that literature results from conscious actions of men in society as the society gives it impetus and direction. Therefore, because poetry is imitative in nature, it is through the study of this imitative human actions as embodied in oral poetry of Abagusii that their feminine ideology is constructed and internalized by Abagusii.

Finnegan (1970) has analyzed the literariness and social functions of various genres of verbal arts. Among the genres analyzed by her study are songs sung by and for children. While taking cognizance of her classification of various sub-genres of African oral poetry, this study has considered the content and specific characteristics of Gusii oral poetry. Of particular significance is Finnegan's assertion that oral texts carry the basic features of literariness and can therefore be analyzed as literary texts. This study has borrowed these general views and henceforth directed them towards the analysis of oral poems of Abagusii as semiotic signs which construct their feminine ideology.

Ngara (1990), has looked at poetry as an artistic production and a medium of human consciousness through which human conception of religion, politics, morality and science is deeply influenced. This basically are people's ideologies. He further singles out categories of ideology which are products of a crucial understanding of poetry. They are: The dominant ideology, the authorial ideology and the aesthetic ideology. In regard to the dominant ideology, he avers that these are the beliefs, assumptions and sets of values that inform the thoughts and actions of people. If poetry is a medium for constructing human consciousness, then this study posits that oral poetry of Abagusii midwives the community's consciousness in regard to the construction of their feminine ideology.

Alembi (1991) has stated that various communities adhere to their specific norms and cultural values which are preserved and conveyed by their oral poetry. This, he says, is a utilitarian dimension of oral poetry. This view echoes Ngugi's (1978) assertion in regard to the sociological significance of literature. This means that oral poetry shapes and directs people's attitudes to their daily struggles with nature, daily struggles with the community and the daily struggles with their souls and selves. In this respect, this study has grounded its choice of oral poetry of Abagusii as a vehicle for studying the feminine ideology of the Gusii community. The effects of this genre are enormous since these oral poems are prescriptive products of the Gusii community whose intentions are to produce grounded and or specific responses from Abagusii people who compose, perform and consume them.

Kichamu and Odaga (1982) have noted that many communities throughout Africa have oral poems which form important parts in the lives and thinking of people. The two have further celebrated that oral poetry is about people's conditions of life hence, they embody the history, philosophy, beliefs and wisdom of the people who produce it. Whereas these views are plausible, they are general to the analysis of oral poetry. This study has borrowed from their approach to move further and demonstrate that the oral poetry of the Gusii community generates ideas whose tenacity is to direct the relationships of Abagusii in their world. 
In the foregoing, borrowing a leaf from the classical studies through to the recent ones, this study has analysed Gusii oral poems bearing that they are culture based, they are bearers of cultural signs and artefacts which in turn embody different aspects of the Gusii ideology, feminine ideology being one of them.

\section{Statement of the Problem}

The timelessness and versatility of oral poetry makes it a powerful vehicle for human socialization. It greatly influences people's perceptions of realities of life. It is therefore this inbuilt ability of oral poetry to construct and influence perceptions of reality that has compelled this study's choice of it to study the nature of the Gusii feminine ideology. The question then is: to what extent then is the oral poetry of Abagusii shaping the community's feminine ideology? Secondly, Alabi (1998) has expounded that literatures with patriarchal orientation cryptically hail women into being "virtuous women", while men are abrasive in character. The next question this study tackles is; could the oral poetry of Abagusii, the poetry they so much enjoy be training Gusii women into being subjects of feelings of inadequacy, feelings of silent frustration and low self-esteem? The observation that a community could inadvertently be celebrating a gender biasness forms the basis upon which this study was undertaken.

\section{Research Methodology}

This study has adopted an analytical research design. It has limited itself to a textual analysis of ten oral poems, this being the thirty percent of Gusii oral poems purposively collected and sampled from a large population of Gusii oral poems bearing the Gusii feminine ideology. They were purposively collected during a field research in the Kisii and Nyamira Counties of Western Kenya. In addition, various contemporary and seasoned oral poets and resource persons were through purposive and snowball methods contacted and interviewed and recorded. Observing and listening to the discourses of those engaged in the performances of the texts equally helped the study to infer some of the feminine constructs conveyed by the sampled oral poems. Lastly, library research and online accessing of information was handy.

\section{Femininity in Gusii oral Poetry}

Femininity has variously been viewed as a set of attributes, behaviours and roles generally associated with girls and women. Femininity as a social ideology is socially constructed. The overall characteristics of femininity are not universally identical but to some extent, patterns such as gentleness, empathy, sensitivity, caring, sweetness, compassion, tolerance, nurturance, deference and humility are foregrounded in regard to femininity. Goffman (1959) has argued that women are socialized to present themselves as precious, ornamental and fragile, uninstructed in and ill-suited for anything requiring muscular exertion and to project shyness, reserve and a display of frailty, fear and incompetence. These traits vary depending on location and context, and are influenced by a variety of social and cultural factors. Butler (1990) has echoed these sentiments by theorizing that gender is not fixed or inherent but is rather a socially defined set of practices and traits that have, over time, grown to become labelled as feminine or masculine.

\section{Feminine Demeanour in Gusii Oral Poetry}

This discussion starts off with analysis of parts of a Gusii oral poem below:

Ekonde seito nkaigwa nyancha aberegete Onchong'a ominto nkaigwa nyancha aberegete!

Nyagetwoni akabutora egetinge

Kabutora egetinge Onchong'a kare moyo

In a synopsis, the conflict in the verse above rests on the basis that a woman; Nyagetwoni- (stereotype) has initiated a divorce process (cutting off her leg ring) in a Gusii patriarchal culture. Such a process, (divorce) the study infers, can only be initiated by men. Her "shameful, nefarious and rebellious" action has driven her husband - Onchong'a into committing suicide. Nyagetwoni is a Gusii cultural sign of feminine contestation of patriarchy while Onchong'a is a Gusii cultural sign which signify the Gusii masculinity - The proud and imperious emissary of Gusii's patriarchal culture. The stereotyping of the biological female in the above oral poem is to construct and interpellate the sociological female into becoming coy and silent, one without a mind and feelings of her own.

In the context of this study, stereotyping is a form of discrimination of the female gender deployed by their male counterparts to maintain their social control over them. Stereotyping is a form of labeling whose aim is to stigmatize the targeted group and finally dissuade and derail it from achieving its objectives in life. The stereotyping of the female gender (Nyagetwoni) in Gusii oral poetry is a harsh verdict of having been found guilty of driving Onchong'a into his premature death. There is no hearing of her side of the story as to what compels her to initiate a divorce process. This appears to be a form of intimidation towards the female gender and its projected result is to maim abrasiveness in females hence, construct a tolerant female who cannot 
question the largesse accorded to the male gender in the Gusii patriarchal culture.

Still in the verse above, the woman commits a sacrilege when she openly expresses her dissatisfaction in a marriage and opts to bolt out. Therefore, Nyagetwoni (the independent minded females in Gusii world) is the embodiment of the condemnation directed towards females with similar thinking among the Gusii community. The purpose is to construct social females who are mellow and humans who should dare not question even that which offends their emotions directly. In this regard, the Gusii female should be gentle and tolerant even in the face of what hurts her most.

The above postulations are further amplified when the semiotic signs in the oral poem below (Egetinkinye Ekeng'aini-Clever Egetinkinye) are interpreted within the Gusii cultural context.

Egetinkinye ekeng'aini
Kerigia Oboundi kiagache
Embura egotwa gesoe!
Gesoe mwaye
Mbura egotwa gesoe mwaye!
Ching'ende chikarangwe
Korwa Nyakongo
Omwana bw'omonda tagochiria
Tagochiria mwana bw'omonda tagochiria

Ing'ererie orotambe

ong'e nduserie abanto roche

Orweng'e ne engegu rwaereire!

Ing'ende Kwabusera omogondo,

Omogondo nyakieni kebariri

Omoiseke omomwamu nyakebwato ogotira

Komonyene chimori namoroche

Namoroche baba- monyene chimori

Ing'ererie chimori ntangere nyakebwato

Tanya kona gotira emanga.

Omoiseke omomwamu nyakebwato

Okonya gotira

Komonyene chimori namoroche

Monyene chimorii

Ing'ererie chimori

Ntangere nyakebwato baba

Tanya kona gotira emanga.
Little clever Egetinkinye

Finds a safe place to build

When it rains, it enters

To shelter in its own home

When it rains, it shelters

To enjoy fried beans

From Nyakongo market

A rich person's child cannot enjoy them!

Beans not enjoyed by the rich

Get me a long fishing line

For fishing humans

The shorter one ends at the bank

To clean up the garden

A garden with red soils

Dark lady with big thigh

Owner of cattle has noticed her

He has spotted her

Hand me cows to prevent her

From roaming at the Manga Escarpment

The dark lady with heavy thigh

Restlessly walking up

The calves' owner has seen her

The owner of calves has seen her

Give me cows

To prevent Nyakebwato

From moving aimlessly on Manga

The subject matter of the oral poem above, Nyakebwato - a Gusii cultural sign for a mature woman and ripe for marriage, has a social need. Her restlessness - Kona gotira emanga - wandering up and down the Manga Escarpment is the need - the need to get engaged in a heterosexual relationship that can lead into a marriage. Curiously, her socio - cultural ability to eloquently voice her intentions have been muted in the poem. From the onset of the poem, she is socialized to take up a mellow and passive trait in regard to the initiating of heterosexual relations. This should be understood from the perspective that humans have the power of the word to state and express their emotions state their intentions. She is made an object - coy and her movements up and down the Manga escarpment are signs of emotional restlessness but she cannot voice her concerns. Apparently, the poem intimates that she is in need of a male companion for a relationship but her voice is muted by the oral poem. She is constructed to exhibit traits of gentleness and silence as she awaits to be told to do what she already plans to execute but cannot. In essence, the female gender is being interpellated into passivity in the whole process of forming heterosexual relations, and to a larger extent, in taking up the lead role in anything.

The patriarchal ideology which is cryptically responsible for constructing femininity in the Gusii cosmos is amplified in the oral poem above when it projects the male as the one to initiate the heterosexual relationship that the female is so much in need of. Komonyene chimori namoroche - The owner of cows (a man) is has seen her.
Ing'ererie orotambe
ong'e nduserie abanto roche
Orweng'e ne engegu rwaereire!
Ing'ende Kwabusera omogondo,
Get me a long fishing line
For fishing humans
The shorter one ends at the bank
To clean up the garden

In the four lines above, the persona, obviously a man, is using dowry (Chimori) to fish out Nyakebwato from her maiden home. The image of a fish being pulled out of water constructs images of coercion. The female is projected as "not willing" but one who is forced not to openly show and talk about her intentions. It thus can be deduced that the oral poem here constructs a coy female, one with a lackadaisical demeanour even in issues 
that directly affect her life.

Further into the construction of a subdued femininity in the Gusii world in the verse below, from an oral poem whose subject matter is: Amache Nyambiriato - Water at a stream called Nyambiriato.
Omokungu siomia siomia ee ee ee baba
A vagrant woman
Omokungu siomia siomia
A vagrant woman
Kayi akomanya bwarugeirwe
She tells where food is ready
Komanya bwarugeirwe ee ee baba
Kai'komanya bwarugeirwe
Where food is ready
Gose mboke gose mbwa'mwana.
She knows where food is ready
Whether little or for child

The verse above is kind of sarcastic. It mocks the careless and aimless movements of a woman just like it is the case with Nyakebwato in the poem Egetinkinye Ekeng'aini whose sections have been analyzed in the section above. In these two oral poems, there is the portraiture of a gender that requires to be contained in the Gusii cosmos. Visiting friends and relations isn't bad but the going from one homestead to another within the same locality (siomia siomia) is injurious to good neighbourliness. It is undignified and nefarious more so given that her mission is to find out what types of foodstuffs have been prepared. These two signs are further amplified in the verse below; equally extracted from the oral poem titled Egetinkinye Ekeng'aini.
Omoiseke Gechemba kore omogenki
Gechemba the gossiper
Obere mino tocha kongenkera Sarange-
Ing'ererie ekerori nyakobugeria ---
Nario Sarange atachi ande!
Stay away from inciting Sarange
Hand me a flute to play
So, that Sarange doesn't leave

This sign of a vagrant woman in the oral poem titled Amache Nyambiriato, just like the sign of Gechemba in the verse above is to construct a social-culturally soft (confined) woman who is interpellated to be reserved and occupy the innermost orbit of the Gusii physical world. In the two verses above, it is stereotyped that the female gender possesses an innate instinct to cause discomfort in the Gusii world. Gechemba is a threat to Sarange's marriage just like Omokungu Siomia siomia - vagrant woman is projected to be a threat to the spirit of good and tranquil neighbourliness. As intimated earlier in this discussion, sstereotyping is a form of labeling whose target is to stigmatize an individual or a targeted group and finally dissuade and derail them from self confidence. When the oral poems discussed in this part of this study grace Gusii social functions and practices, the recipients - women are socially interpellated into becoming subjects of a Gusii feminine ideology which stipulates that they should remain humble, mellow, passive and sensitive lest derogatory epithets like siomia siomia, Nyakebwato, Nyagetwoni and others be tagged on them.

Still on the same argument, it is worth noting that gossip, a negative tag and for this matter a stereotype, has been attributed to Gechemba. Gechemba is a cultural sign for a constructed female character which signifies limited intelligence and the destructive nature of the mature but unmarried women in the Gusii world. Whereas the sign Omoiseke Gechemba kore omogenki - Gechemba the lady gossiper, Obere mino tocha kongenkera Sarange - Stay at your home and avoid coming to my place to negatively influence (Swahili - Kuchochea) Sarange, it conversely constructs the man in the Gusii environment as a wise person. Such are the stereotypes that the same feminine ideology deploys in assigning feminine gender passive roles, roles that dissuade them from any form of social, economic and political independence.

If the female gender is socialized to stay at home, it is a social construction geared towards constructing a coy and mellow female. In the case of the poem quoted above, marriages are threatened in case the female is allowed to have a voice. It is the position of this discussion that marriage is a microcosm for the socio - cultural harmony. Therefore, if Gechemba's freedom of expression is a threat to marriage, on a wider scale the implication is that if the feminine gender is granted freedom of expression and association, then the social harmony and integration of the Gusii community is in jeopardy. Consequently, it is thus clear that the oral poetry of the Abagusii constructs a feminine ideology which silences its girl - child, hence, a gender that is forever to remain tender.

\section{Feminine Roles in Gusii Oral Poetry}

Femininity in Gusii cosmos goes beyond character traits and emerges strongly in the area of gender roles assigned to the female gender. These gender roles are designed and assigned to justify the gender strereotypes, some of which have been discussed above. Gender stereotypes influence traditional feminine occupations, resulting in microaggression toward women who break traditional gender roles like is the case with Nyagetwoni above. In regard to the roles of the female gender, this study starts off its discussion with the analysis of a section of one of the Gusii intitiation oral poems locally known as Esimbore.

\author{
Tamotoma roche, \\ Tamotoma rocheee! \\ Taa nyeni taa nyeniii! \\ Tachia koruga tachia korugaaa!
}

Should not send him to fetch water!

Should not send him to fetch water!

Should not send him to pluck vegetables

Should not cook meals 
Initiation marks a transition from childhood to adulthood. Consequently, this study takes the position that oral poems performed during such cultural festivals are laden with strictness of meanings in regard to what is expected of one in in the life of adulthood. The verse above from an initiation oral poem of Abagusii a semiotic command to women (mothers of initiates) not to ask their sons; now men, to perform certain tasks such as fetching water from streams and plucking vegetable leaves. The sociological implication here is that these are household - related jobs which in this case should be undertaken by the females. This is a reinforcement of the stereotype that women are frail, fragile and tender and therefore should be restricted into performing household chores duties of fetching water, plucking vegeatable leaves and cooking. Definately, this is a domineering and subjugating construction of patriarchy which is keen on restricting women to domestic works as the male gender explores the world yonder where new ideas emanate.

Further into the construction and portraiture of feminine roles as part of the feminine ideology of Abagusii is the verse below from an oral poem titled: Obori bwa Baba-Mama's Finer Millet

$\begin{array}{ll}\text { Obe e-e-e sabiri kumba! } & \text { Kindly Sabiri, bend } \\ \text { Kumbata mogondo are! } & \text { She is tilling the farm } \\ \text { Obe e-e-e buna abakoro! } & \text { Like women of the old } \\ \text { Kumbata mogondo are } & \text { Tilling like women of the old } \\ \text { Obe e-e-e Choisi bwari! } & \text { Joyce Bwari } \\ \text { Kumbata mogondo are } & \text { She is tilling the farm } \\ \text { Obe e-e-e Choisi Nyairo! } & \text { Hail Joyce Nyairo } \\ \text { Kumbata mogondo are } & \text { She is tilling the land }\end{array}$

Just like the verses analyzed above, the content in the verse above is grounded on stereotypes meant to subjugate the female gender. The names of the individuals being praised for being hard working - Sabiri, Joyce Bwari, Joyce Nyairo are all feminine names. The part of interest for this study is the kind of job they are being praised for having accomplished. It is the tilling of land. This is great contrast to the ownership of livestock which has been assigned to the male gender in the oral poem titled Egetinkinye Ekeng'aini, whose parts have been foregrounded in the discussion above. The stereotype here is that members of the female gender have greater manual dexterity hence they have been socialized into being subjects of a feminine ideology to which they have to be active in their role of tilling the land.

Other than the roles of being domestic workers and farm tillers, the feminine ideology of Abagusii has been constructed by the community's oral poetry to see to it that the female are happy as wives, midwifes, and child bearers. This is amplified the lines below taken from an oral poem celebrated by Abagusii:
Goko okorire buya
Granny has done well,
Abarete egeita
She is going to pass through the cattle pen!
Orenge moka abaisia
She was a wife to uninitiated boys,
Obeire moka abamura
Now she is a wife for initiated men

In the above lines, a young lady is being praised, definitely after initiation, to become a wife of initiated men. Equally, in the poem Egetinkinye Ekeng'aini, see below:
Omoiseke Gechemba kore omogenki
Gechemba the gossiper
Obere mino tocha kongenkera Sarange-
Stay away from inciting Sarange
Ing'ererie ekerori nyakobugeria ---
Nario Sarange atachi ande!
Hand me a flute to play
So, that Sarange doesn't leave

there is Sarange, a wife who is praised for being dormant and contented with her social position as a wife. In these two cases, it is evident that the Gusii oral poetry constructs a feminine ideology in which social patterns create domination and suppression. In this regard, femininity as an ideology of Abagusii is constructed in such a manner that the females are relegated into the roles motherhood because they are caring and can nurture lives.

The other prominent role that is constructed and assigned to the female gender according to the oral poetry of Abagusii is the role of the female being social workers. The oral poem whose parts are quoted below is performed alongside other praise poems in weddings and or in related occasions. Studying the verse below will reveal a concerted effort to mute the feminine voice and construct a mellow female who is subjugated into the subordinate role of entertainment and therefore being socialized into becoming a social worker.
Moite buya konyatundo Nyarisinange
Nyieria buya konyatundo Nyarisinangee -
Dance like Nyadundo of Sinange
Tuma buya konyatundo Nyarisinangee -
Smile like Nyadundo of Sinange
Suna buya konyatundo Nyarisinangee- Jump like Nyadundo of Sinange
Pinch like Nyadundo of Sinange
Chenchia buya konyatundo Nyarisinangee-
Dance like Nyadundo of Sinange
Nyadundo of Sinange greet Onchuru

Nyadundo stands for short and beautiful woman who hails from a region called Sinange. This oral poem constructs a scenario in which it is the womenfolk who should be at the forefront in the entertainment of those attending social functions. The refrain above, interrogated with keenness, reveals a construction of a social 
environment in which a gender which celebrates an oral poem which curtails its freedom of expression. The point is; the refrain directs them into dancing, smiling and jumping; mere physical actions which are meant for the entertainment and gratification of the eyes of the spectators, in this case, most probably men.

As the poem instructs the woman to jump, dance and smile, it is the postulation of this study that the intent of this poem together with other is to construct a feminine ideology which socializes the female gender into taking up the roles receptionists, housekeeping, salespersons and such like gender roles which demand that one should either be dancing, smiling or jumping up to please others. In reality, in more than one respect, these feminine roles are subordinate to those assigned to the male gender. In essence, these social femininities slowly glorify the retributive macho position of men and slowly but steadily, it stereotypes and stigmatizes the trickery and any sense of brainwork which can aid the female gender in working out their own emancipation. Ultimately, the image of the female gender as constructed is that of a feminine entity that is coy, whose voice is muted but her actions are quite visible.

\section{SUMMARY AND CONCLUSION}

Femininity as a part of a community's social ideology is an elaborate subject that cannot be fully covered in such a brief discussion. This paper covers just a section of the Gusii feminine ideology. This study has examined Gusii oral poetry and has documented here in some of the traits and stereotypes that are cryptically embedded in these poems. Equally, while establishing the construction of femininity in Gusii oral poetry, this study has established some of the roles which these poems have assigned the female gender. They are roles derived largely from feminine stereotypes. They include household chores, manual works, social works among others. Therefore, it is the submission of this paper that not all has been covered in regard to the portraiture of femininity in Gusii oral poetry. Therefore, further investigation into this rich area of the Gusii oral poetry is recommended.

\section{REFERENCES}

Abdurrahman, U. (2018). New studies in African literature. Ibadan. Kraft Books Limited.

Akewula, O. A. (2016). Gender, Women and world in Fawziyyah Al-Bakar's Hayatu min waraqin. A paper published in Ibadan Journal of Humanistic Studies. Ibadan. Faculty of Arts, University of Ibadan. Nigeria.

Akivaga, S.; \& Odaga, B. (1982). Oral literature: A school certificate course. Nairobi. East African Publishing Press.

Alabi, A. (1998). “Gender issues in Zeynab Alkali's Novels” In Childhood in African Literature. Oxford: James Currey Limited.

Albrecht, M. (1978). The relationship of literature and society: Literature taste, culture and mass communication Vol 6. The sociology of literature. Peter Davidson et el. Chadwyek; Healy Ltd.

Alembi, E. (2003). Singing and dancing the rhythm of life oral poetry in the Banyole community of Kenya. Accessed From www.elore.fi/arkisto/1 03/ale103.html.

Alkali, Z. (1987). The virtuous woman. Nigeria. Longman UK Limited

Althusser, L. (1971) Ideology and Ideological State Apparatuses' Lenin and Philosophy and Other Essays. London. Monthly Review Press.

Amateshe, A. (1988). An anthology of East African Poetry (edited). Essex. Longman UK Limited.

Anyidoho, K. (1983). Oral poetics and Traditions of Verbal Art in Africa. Unpublished PhD dissertation, University of Texas at Austin.

Badejo, Diere. (1999). African Feminism: Mythical and Social Power of Women of African Descent. African Gender Research. Vol. 2 (1): 22-48. Ibadan. Kraft Books Ltd.

Barbara, T. (2005) The woman in the shaman's body: reclaiming the feminine in religion and medicine, Random House Digital, Inc., 2005

Barthes, R. (1964). Elements of Semiology (trans. Annette Lavers \& Colin Smith). London: Jonathan Cape.

Beauvoir, S. (2010). The Second Sex. New York Press

Bell, D. (2000) The end of ideology: On the exhaustion of political ideas in the fifties. ( $2^{\text {nd }}$ ed $)$ Cambridge, Mass: Harvard University Press.

Bogonko, S. N. (1977). Christian missionary education and its impact on the Abagusii of Western Kenya. Nairobi. (Unpublished doctoral Thesis), University of Nairobi.

Bukenya, A., Wanjiku, K., \& Okombo, O. (1994). Understanding oral literature. (Eds) Nairobi: Nairobi University press

Bukenya, A. \& Gachanja, M. (1997). Oral literature. A senior course. Nairobi: Longhorn Publishers (K) Ltd.

Butler, J. (1990). Gender Trouble: Feminism and the Subversion of Identity. Routledge.

Bwonya, J. (2013). Gender spaces in Maragoli children's play poetry. (Unpublished doctoral thesis), Department of Literary Studies. Maseno University, Kenya

Chandler, D. (2005). Semiotics for Beginners. Aberystwyth: University of Wales. Aberystwyth.

Chesaina C. (1991). Images of Women in African Oral Literature: A case Study of 
Cook, D. \& Rubadiri, D. (1974) Poems from East Africa. Nairobi, Heinemann Kenya Limited

Curthoys, A. (1988). For and against feminism: A personal journey into feminist history and theory. Sydney: Allen and Unwin.

Eagleton, T. (1976). Marxism and literary criticism. Los Angeles University of California Press,

Empson, W. (1930). Seven types of ambiguity. London: Cambridge University press.

Eyoh, L. \& Clark, J. P. (2005). Bekederemo's poetry: A studying stylistic criticism. Uyo: Scholars Press.

Eyoh, L. (2013). Indigenous oral poetry in Nigeria as a tool for national unity. Lagos. University of Uyo.

Finnegan, R. (2007). The oral and beyond: Doing things with words in Africa. Oxford: Chicago University.

Frederick, E. \& Hander, G. (1960). The child and society: The process of socialization. Randon House.

Gayatri, C. S. (1988). Can the subaltern speak? In literary criticism. Addison Wesley.

Habib, M. (2005). A History of literary criticism - From Plato to the present. Oxford. Blackwell press.

Hale, M. \& Stephen, E. (2010). Masculinity and Femininity in the MMPI-2 and MMPI-A. University of Minnesota Press.

Hofstede, G. (1998). Masculinity and Femininity: The Taboo Dimension of National Cultures. SAGE Publications.

Hollows, J. (2000). Feminism, Femininity and Popular Culture. Manchester University Press.

Joanne, H. \& Rachel, M. (2006). Feminism in Popular Culture. Berg Publishers.

Kabira, W. M. (1993). Images of women in Gikuyu oral narratives. (Unpublished doctoral Thesis). Nairobi

Kabira, W. M, \& Mbugua, W. (1994). Delusions: Essays on social construction of gender. Nairobi. UoN

Kothari, C.R. (2010). Research methodology: Methods \& techniques (3 ${ }^{\text {rd }}$ Edition). New Delhi: New Age International Publishers.

Levine, R. \& Levine, B. (1956). Nyansongo: A Gusii community in Kenya. New York. John Willey.

Liyong, T. (1972). Popular culture for East Africa. Nairobi. Longman.

Marianne, W. (1997). Reinventing the sexes: the biomedical construction of femininity and masculinity. Race, gender, and science. Indiana University Press.

Mayer, P. (1953). Ekeigoroigoro: A Gusii Rite of Passage. Man, Gusii initiation. University of Nairobi

Miruka, O. (1999). Studying oral literature. Nairobi: Acacia Publishers

Muleka, J. H. (2002). The portrayal of girl characters in selected children's books in Kenya. Kenyatta University

(2009) Images of women in African oral literature. A study of Abakhayo marriage oral poetry. VDM Verlag. German

Nandwa, J. \& Bukenya, A. (1983). African oral literature for schools. Nairobi: Longhorn Publishers.

Nyambane, et al (2014). Oral poetry for environmental conservation - Analysis of selected Gusii Song texts. http://jeteraps.scholarlinkresearch.com/listofissues.php

Ochieng, W. R. (1974). Pre-colonial history of the Gusii of western Kenya. from A.D 1500 to 1914.

Nairobi: East African Literature Bureau.

Ogembo, J. (2001). An Exploration into Gusii personification of evil. http://www.Jstor .org/stable/640584. Accessed: 12.02.2012 13:52

Pamela J.; \& Michael, J. (1995). Gender, power, and communication in human relationships. Psychology Press.

Ria, K.; \& Wouter, J. (1995). Female stereotypes in religious traditions. Brill Press

Serano, J. (2007). Whipping Girl: A Transsexual Woman on Sexism and the Scapegoating of Femininity. Berkeley: Seal Press.

Woolf, V. (1989) A Room of One's Own. San Diego: Harcourt Brace Jovanovich.

Williams, T. (2011). Inventing Womanhood: Gender and Language in Later Middle English Writing. Ohio State University Press. 


\section{KONDE SEITO}

Ekonde seito nkaigwa nyancha abenegete Onchong'a ominto nkaigwa nyancha abenegete Nyagetwoni akabutora egetinge Kabutora egetinge Onchong'a kare moyo Bwabokire! Bwabokire obwanchani Bori bwa kare, bori bwakare obwanchani Bwabokire, bwabokire obwanchani Tema naende, tema naende torore Yaye abana baito - ee kwania Obino Ase rituko buna riarero!! Ooh! Aye Onchong'a agatanga ekworo Eee kwani Obino

\section{KONYATUNDO NYAR'SINANGE}

Moite buya konyatundo Nyarisinange Nyieria buya konyatundo NyarisinangeeTuma buya konyatundo NyarisinangeeSuna buya konyatundo Nyarisinangee Chenchia buya konyatundo NyarisinangeeEee! Nyatundo Nyarisinange Kwani Onchuru

\section{ESIMBORE}

Baisia bake bororo bwabarire! Isemokami oirire mboro chiaito; Batureirwe itimo na nguba mbibo. Barwane Sigisi, barwane Sigisi! Barwane bosoba, barwane Bosoba! Baisia bake e-e-e, bororo bwabarire Isono ria ng'ina, isono ria ng'ina, Oboya bwa ng'ina, oboya bwa ng'ina, Baisia bake teta ng'ina, teta ng'ina! Baisia bake bororo bwabarire

\section{ESIMBORE -}

Goko okorire buya Abarete egeita

Orenge moka abaisia

Obeire moka abamura

Igesora na igesora,

Totegorere amaboba

Simbore yaito yarure rogoro

Nyambegera moka Asago

Oirire ebisono biaito

Ochire kogekera!

\section{APPENDIX - GUSII ORAL POEMS}

\section{WHILE AT HOME}

While home, I heard He's drowned

Onchong'a has drowned in Lake

Nyagetwoni had cut her legring

Cut legring yet Onchong'a was alive

Real love has been rekindled

Love of the old times is alive

Real love has been rekindled

Try once again, let's see

Ohh! Our children, greet Obino

On a day such as this one

Onchong'a thought only of himself

Ooh yes, greetings to Obino

\section{LIKE THE BEAUTY OF SINANGE \\ Dance like Nyadundo of Sinange Smile like Nyadundo of Sinange Jump like Nyadundo of Sinange Pinch like Nyadundo of Sinange Dance like Nyadundo of Sinange Nyadundo of Sinange greet Onchuru}

\section{CIRCUMCISION POEM}

Uncircumcised little boys have felt pain! The circumciser has taken our penis; He has made them a spear and a hard shield. Fight the Kipsigis! Fight the kipsigis! Fight the Abasuba, fight the Abasuba! Uncircumcised little boys have had pain! Mother's clitoris, mother's clitoris, Mother's pubic hair, mother's pubic hair, Uncircumcised little boys, copulate with mother! Uncircumcised little boys have had pain!

\section{FEMALE CIRCUMCISION SONG.}

Granny has done well, She is going to pass through the cattle pen! She was a wife to uninitiated boys, Now she is a wife for initiated boys, After harvest, after harvest, We shall cultivate our second crops Our esimbore song has come from up yonder, Nyambegera, the wife of Asago,

Has taken our clitoris

And has gone to roast them! 


\section{EGETINKINYE EKENG'AINI}

Egetinkinye ekeng'aini

Kerigia Oboundi kiagache

Embura egotwa gesoe!

Gesoe mwaye

Mbura egotwa gesoe mwaye!

Ching'ende chikarangwe

Korwa Nyakongo

Omwana bw'omonda tagochiria

Tagochiria mwana bw'omonda tagochiria

Ing'ererie orotambe

ong'e nduserie abanto roche

Orweng'e ne engegu rwaereire!

Ing'ende Kwabusera omogondo,

Omogondo nyakieni kebariri

\section{CLEVER BIRD}

Little clever bird

Finds a safe place to build

When it rains, it enters

To shelter in its own home

When it rains, it shelters

To enjoy fried beans

From Nyakongo market

A rich person's child cannot enjoy them!

Beans not enjoyed by the rich

Get me a long fishing line

For fishing humans

The shorter one ends at the bank

To clean up the garden

A garden with red soils

Omoiseke omomwamu nyakebwato ogotira Dark lady with big thigh

Komonyene chimori namoroche Namoroche baba-monyene chimori

Ing'ererie chimori ntangere nyakebwato

Tanya kona gotira emanga.

Omoiseke omomwamu nyakebwato

Okonya gotira

Komonyene chimori namoroche

Monyene chimorii

Ing'ererie chimori

Ntangere nyakebwato baba

Tanya kona gotira emanga.

Omoiseke Gechemba kore omogenki

Obere mino tocha kongenkera Sarange-

Ing'ererie ekerori nyakobugeria ---

Nario Sarange atachi ande!

Owner of cattle has noticed her

He has spotted her

Hand me cows to prevent her

From roaming at the Manga Escarpment

The dark lady with heavy thigh

Restlessly walking up

The calves' owner has seen her

The owner of calves has seen her

Give me cows

To prevent Nyakebwato

From moving aimlessly on Manga

Gechemba the gossiper

Stay away from inciting Sarange

Hand me a flute to play

So, that Sarange doesn't leave

\section{EKERANDI KIO OMONG'INA}

Ekerandi kiomong'ina

Egesero-a, egeseraa aigwanane

Egesero kiomwana,

Egeseraa, egeseraa, aigwanane

Egeteni kiomogaka ---

Okirigiti osangara,

Ooo yaye!

Onsinsi nakana ensarera nse,

Onsinsi akarera

Nyakieni tonkeria

Ntaba Mogirango 'Ndindindi!

Eroo ondire tonkereria

Ondire Orogendo.

\section{MOTHER'S GUARD}

The grandmother's guard

Let all be at peace

The hide meant for the baby

Let all live together in peace

Father's three-legged stool

Okirigiti the son of Onsangare

Ohh yes

Onsinsi I refuse the line of gossipers

Onsinsi wept

The beautiful one do not refuse

I'm not from Mugirango

Oh yes, you've cost me, let me down not

Has cost me a long journey 


\section{OMOISEKE NYAKIENI KEBARIRI}

Kerama ngweta

Mwaira engero geita

Kerama aero Nyando

Bengi tene Nyarere

Mwaira engero geita

Kirimaoero nyando.

Noraire?

E- baba omwana atacha

Antebia ebaba rigereria

Irongo tuki chinge kiomonyoncho,

Kunya! Kerebi

Moka masuti ogocha

Gotorigia engangangarayo.

Ebinde bia amagoro, engangarayo

Tee engangangarayo

Mokamosomba korera mariga

Omoiseke nyakieni keberiri

Otigire ekieni Bobaracho

Otigire ekieni Kebarache,

Nga'i abamura baratare

Eee ng'ai torachie, ee ng'ai torarare

Abang'ina baboria boira

Abamura gaki takona korera

Korera nyoko na iso,

Moiseke nyoko bisira,

\section{OBORI BWA BABA}

Obori bwa baba ekeande

Ee ekeande obori bwa baba,

Obori bwa baba ekeande,

Ekeande baba omotengera nyangueso

Ndindindi! Ndindindi ndindindi!

Amaembe a baba amatogoro

Ee amatogoro amemba a baba!

A-amaemba a baba amatogoro,

Amatogoro baba omotengera nyangueso

Ndindindi! Ndindindindi ndindindi.

Enyangweso yacha yaboria

Eeh yaboria, Enyangweso yacha

Enyangweso yacha yaboria,

E yaboria baba omotengera

Nyangweso Ndindindindi

\section{THE BROWN GIRL}

Passing near Kerama

You've taken the dance at the gate

Kerama near Nyando

Bengi tena Nyarere

You've taken the dance to the gate

Kirima oero Nyando

Are you asleep?

Hey mum, the child hasn't come

Tells me mammy, just have a look

Inside the ceiling,

Kunya, Kerebi

When Masuti's wife comes,

To look for us

And foot steps engangarayo

Tee engangangarayo

The wife of Mosomba weeps

The girl with the brown complexion

Has left the complexion at Bobaracho

Has left her complexion at Kebarate

Where will men take their walk to?

Where shall we go to?

Old women are asking daily

Young men stop weeping

Stop crying for mother and father's help

The girl, the mother to Bisira

\section{MOTHER'S FINGER MILLET}

Grandmother's finger millet has done well Grandmother's millet has yielded well Grandmother's millet has yielded well Great harvest as grandma dances to locusts Ndindindi! Ndindindindi ndindindi

Grandmother's sorghum has yielded well

The sorghum has yielded well

The sorghum has yielded well

Great harvest as grandma dances to locusts Ndindindi! Ndindindindi ndindindi

The swam of locusts come

A swam of locusts comes and consumes

The swam of locusts comes

As granny dances for the locusts

Dances ndindindi 


\section{AMACHE NYABIRIATO}

Amache Nyambiriato ee baba

Amache nyambiriato amache nobochege agiteirwe

Nobochege agiteirwe ee baba, nobochege

Agiteirwe amache nyamotika egocha enywe,

Oyotagete emeino ee ee baba-

Oyotagete emeino agende Nyamataro obitogia

Nyamataro obitogia ee baba,

Nyamataro obitogia ase emeino ekoiywa nebitonga

Borangi yoka ngumbuu ee baba

Yakang'umbu Mogonche chinguba chiana kuoma

Chinguba nchiana kwoma ee baba

Nguba nchiana kwoma rogoro boisanga renda mache

Nche timbwati ng'ombe-ee -- ee baba

Nche timbwati ng'ombe, amache nobochege agiteirwe

E nobochege agiteirwe - ee baba, e nobochege agiteirwe

Agiteirwe ee baba e amache nobochege agiteirwe.

Amache Nyambiriatoo ee ee ee baba

\section{WATERS AT NYAMBIRIATO}

The water at Nyambiriato

Is fenced off---

to keep off intruders

So that Nyamotika drinks it

One who to knows our ways,

He should go to Nyamataro

Nyamataro praises our ways

Nyamataro, praises our ways

At Borangi side of the ridge,

Shields are in plenty

They are so many of them

shields are never scarce

I've got no cows

I've no cows, well is fenced

To keep off intruders

Fenced, to keep away thiefs

The waters at Nyambiriato

\section{MOGOTU MOGA TEBITI - MOGOTU- DAVID'S WIFE}

Moga tebiti, Mogotu mogatebiti ee!

Moga tebiti mokungu akaimokia omoro ee!

Akaimokia omoro agende goita tebeti

Bikundo okorera, kogicha ntayiete omonwa,

Ntayiete omonwa nka monwa chibesa.

Mokanyandondi, Moraa mokanyandondi ee!

Mokanyandondi mokungu akaimokia omoro- ee!

Akaimokia omoro agende goita Nyandondi

Bikundo okorera kogicha ntayiete omonwa
Mogotu, David's Wife

Mogotu took a machette

To murder David

Bikundo is weeping

Bikundo regrets having ben born

Moraa, Nyandondi's wife

A woman took a machette

Took a machette to murder Nyandondi

Bikundo weeps, I never burnt my mouth 